\title{
Pengaruh Model Pembelajaran Scramble Berbantuan Permainan Crossword Fuzle terhadap Kompetensi Pengetahuan IPA
}

\author{
Pt. Dian Novita Sari ${ }^{*}$, I Wayan Darsana², Made Putra3 \\ 1 Jurusan PGSD Universitas Pendidikan Ganesha Singaraja, Indonesia \\ 2 Jurusan PGSD Universitas Pendidikan Ganesha Singaraja, Indonesia \\ ${ }^{3}$ Jurusan PGSD Universitas Pendidikan Ganesha Singaraja, Indonesia
}

\begin{abstract}
Abstrak
Tujuan penelitian ini untuk mengetahui perbedaan yang signifikan penguasaan kompetensi pengetahuan IPA antara kelompok siswa yang dibelajarkan menggunakan model pembelajaran scramble berbantuan permainan crossword fuzle dan kelompok siswa yang dibelajarkan menggunakan pembelajaran konvensional pada siswa kelas IV SD Gugus I Gusti Ngurah Rai Denpasar Utara tahun ajaran 2017/2018. Jenis penelitian ini merupakan eksperimen semu dengan desain penelitian nonequivalent control group design. Populasi penelitian ini adalah siswa kelas IV di SD Gugus I Gusti Ngurah Rai Denpasar Utara tahun ajaran 2017/2018 sebanyak 323 orang yang tersebar dalam 9 kelas. Sampel ditentukan dengan teknik random sampling. Sampel penelitian ini adalah siswa kelas IVA SDN 4 Ubung sebagai kelompok eksperimen dan siswa kelas IVB SDN 3 Ubung sebagai kelompok kontrol. Data penguasaan kompetensi pengetahuan IPA dikumpulkan dengan instrumen berupa tes objektif pilihan ganda biasa berjumlah 37 butir soal yang divalidasi. Data penguasaan kompetensi pengetahuan IPA dianalisis dengan t-test. Hasil analisis menunjukkan terdapat perbedaan yang signifikan penguasaan kompetensi pengetahuan IPA antara kelompok siswa yang dibelajarkan menggunakan model pembelajaran scramble berbantuan permainan crossword fuzle dan kelompok siswa yang dibelajarkan menggunakan pembelajaran konvensional pada siswa kelas IV SD Gugus I Gusti Ngurah Rai Denpasar Utara tahun ajaran 2017/2018. Hal tersebut dibuktikan dengan hasil thitung $=4,833$ dan pada taraf signifikansi $5 \%(\alpha=0,05)$ dengan $\mathrm{dk}=(34+36)-2=68$ diperoleh ttabel $=2,000$. Berdasarkan kriteria pengujian thitung $=4,833>\operatorname{ttabel}(\alpha=0,05)=2,000$. Demikian pula nilai rerata penguasaan kompetensi pengetahuan IPA siswa kelompok eksperimen $X^{-}=0.505>X^{\prime}=0.331$ rerata penguasaan kompetensi pengetahuan IPA siswa kelompok kontrol. Dengan demikian dapat disimpulkan bahwa pembelajaran scramble berbantuan permainan crossword fuzle berpengaruh terhadap penguasaan kompetensi pengetahuan IPA siswa kelas IV di SD Gugus I Gusti Ngurah Rai Denpasar Utara tahun ajaran 2017/2018.

\author{
scramble, permainan \\ crossword fuzle, \\ kompetensi \\ pengetahuan IPA
}

Keywords:
\end{abstract}

\section{PENDAHULUAN}

Memasuki zaman globalisasi seperti sekarang ini yang ditandai dengan pesatnya perkembangan teknologi, mewajibkan suatu wilayah atau Negara memiliki sumber daya yang mendukung. Salah satunya adalah sumber daya manusia yang berkualitas. Sumber daya manusia yang berkualitas dapat dihasilkan salah satunya melalui Pendidikan.

Selain itu, Undang-Undang Sistem Pendidikan Nasional No. 20 Tahun 2003 berbunyi bahwa Pendidikan Nasional bertujuan untuk mengembangkan potensi peserta didik agar menjadi manusia yang beriman dan bertakwa kepada Tuhan Yang Maha Esa, berakhlak mulia, sehat, berilmu, cakap, kreatif, mandiri dan menjadi warga Negara yang demokratis serta bertanggung jawab. Pendidikan harus dilaksanakan secara optimal sehingga dapat memberikan dampak positif terhadap perkembangan bangsa (Artini, 2014)

Pendidikan adalah sarana yang memiliki peranan sangat penting untuk mengembangkan mutu sumber daya manusia. Untuk merealisasikan tujuan dari Pendidikan Nasional tersebut, berbagai upaya 
telah dilakukan oleh Pemerintah. Upaya tersebut salah satunya adalah menyusun dan menyempurnakan Kurikulum. "Kurikulum adalah seperangkat rencana dan pengaturan mengenai tujuan, isi dan bahan pelajaran serta cara yang digunakan sebagai pedoman penyelenggaraan kegiatan pembelajaran untuk mencapai tujuan pendidikan tertentu" (Mulyasa, 2009:46). Kurikulum Tingkat Satuan Pendidikan (KTSP) yang diterapkan pada tahun 2006 telah mengalami proses revisi oleh Pemerintah dan kemudian disempurnakan menjadi Kurikulum 2013. Pergantian Kurikulum ini adalah upaya Pemerintah untuk meningkatkan kualitas pendidikan di Indonesia. Dalam Kurikulum 2013 siswa dituntut melalui beberapa proses secara aktif mencari, mengolah, mengkonstruksi dan menerapkan pengetahuan. Maka sangat diperlukan upaya inovasi guru dalam mensiasati pembelajaran di kelas.

Berdasarkan observasi dengan beberapa guru kelas IV di semua SD Gugus I Gusti Ngurah Rai Denpasar Utara dalam proses pembelajaran terutama menyangkut bidang IPA masih banyak kelemahan dilihat dari hasil belajar IPA di beberapa kelas siswa yang masih rendah, terutama penguasaan kompetensi pengetahuan. Partisipasi siswa saat pembelajaran kurang aktif, dan pembelajaran IPA tersebut tampak belum menggunakan model - model pembelajaran yang inovatif karena sebagian besar masih menggunakan metode ceramah dan tanya jawab sehingga siswa cenderung cepat bosan dan kurang menyenangkan bagi siswa dalam belajar.

Pelaksanaan pembelajaran dikelas perlu didesain secara kreatif dan inovatif dengan memperhatikan karakteristik perkembangan siswa kelas IV SD. Dari permasalahan tersebut dipandang perlu adanya inovasi dalam pembelajaran yakni pembelajaran yang mengutamakan penguasaan kompetensi, berpusat pada siswa, memberikan pengalaman belajar, meningkatkan konsentrasi dan kecepatan berpikir siswa serta menyenangkan bagi siswa sehingga siswa tidak cepat bosan dalam mengikuti pembelajaran. "Siswa yang bisa merasakan bahwa belajar adalah sesuatu yang menyenangkan akan mempunyai rasa ingin tahu yang besar" (Kosasih, 2014:114), maka dalam penelitian ini peneliti mencoba sebuah model pembelajaran yang berorientasi pada penerapan muatan materi IPA yang menyenangkan. Model pembelajaran yang dimaksud adalah Model Pembelajaran Scramble berbantuan permainan Crossword Fuzle.

"Scramble merupakan salah satu metode pembelajaran yang dapat meningkatkan konsentrasi dan kecepatan berpikir siswa" (Huda, 2013:303). Dalam metode ini, siswa tidak hanya diminta untuk menjawab soal, tetapi juga menerka dengan cepat jawaban soal yang sudah tersedia namun masih dalam kondisi acak. Model pembelajaran ini, mengasah ketepatan dan kecepatan berpikir siswa dalam menjawab soal. Skor siswa ditentukan oleh seberapa banyak soal yang benar dan seberapa cepat soal-soal tersebut dikerjakan.

Permainan crossword fuzle atau yang sering dikenal dengan nama Teka- teki silang ini merupakan salah satu permainan sederhana yang dapat digunakan untuk meninjau ulang seberapa besar pemahaman siswa terhadap materi pembelajaran. "Crossword fuzle dapat dilaksanakan secara tim sehingga dapat melibatkan siswa dan partisipasi secara langsung." (Ngalimun dkk, 2016:228)

Pembelajaran dengan model scramble sangat cocok diterapkan untuk mata pelajaran IPA. Karena selama ini IPA hanya dibelajarkan dengan berpatokan pada buku pegangan dan masih berpusat pada guru sehingga kurang menarik bagi siswa dan siswa juga kurang aktif saat kegiatan pembelajaran. Model pembelajaran scramble akan membuat pembelajaran IPA menjadi lebih menarik dan bermakna karena model ini dapat mendorong keaktifan siswa untuk belajar mengerjakan soal, melatih siswa untuk berpikir cepat dan tepat, sehingga pengetahuan yang didapat oleh siswa tidak bersifat hapalan semata. Selain itu, pembelajaran IPA dengan model pembelajaran scramble akan lebih menyenangkan bagi siswa karena dibantu dengan permainan crossword fuzle. Disaat siswa telah mampu merangkai huruf jawaban dengan benar, tepat dan cepat, maka huruf tersebut dimasukan langsung pada kotak - kotak putih sesuai petunjuk. "Hal ini akan melatih siswa untuk berpikir cepat dan tepat" (Huda, 2013:306). Sehingga pengetahuan yang diterima tidak cepat dilupakan oleh siswa dan hasil belajar menjadi optimal.

Berdasarkan uraian tersebut, secara teoritis model pembelajaran scramble berbantuan permainan crossword fuzle berpengaruh terhadap penguasaan kompetensi pengetahuan IPA, tetapi secara empiris perlu dibuktikan melalui penelitian yang berjudul "Pengaruh Model Pembelajaran Scramble Berbantuan Permainan Crossword Fuzle Terhadap Kompetensi Pengetahuan IPA Siswa Kelas IV SD Gugus I Gusti Ngurah Rai Denpasar Utara Tahun Ajaran 2017/2018".

Sesuai dengan judul tersebut, terdapat beberapa tujuan dari penelitian ini yaitu, (1) Untuk mendeskripsikan penguasaan kompetensi pengetahuan IPA kelompok siswa yang dibelajarkan menggunakan model pembelajaran scramble berbantuan permainan crossword fuzle pada siswa kelas IV SD Gugus I Gusti Ngurah Rai Denpasar Utara tahun ajaran 2017/2018. (2) Untuk mendeskripsikan penguasaan kompetensi pengetahuan IPA kelompok siswa yang dibelajarkan menggunakan pembelajaran konvensional pada siswa kelas IV SD Gugus I Gusti Ngurah Rai Denpasar Utara tahun ajaran 2017/2018. (3) Untuk mengetahui perbedaan yang signifikan penguasaan kompetensi pengetahuan IPA antara 
kelompok siswa yang dibelajarkan menggunakan model pembelajaran scramble berbantuan permainan crossword fuzle dan kelompok siswa yang dibelajarkan menggunakan pembelajaran konvensional pada siswa kelas IV SD Gugus I Gusti Ngurah Rai Denpasar Utara tahun ajaran 2017/2018.

\section{METODE PENELITIAN}

Penelitian ini dilaksanakan di SD Gugus I Gusti Ngurah Rai Denpasar Utara yaitu di SDN 3 Ubung dan SDN 4 ubung. Adapun alasan dipilihnya SD Negeri di gugus ini karena di SD tersebut telah menerapkan kurikulum 2013, tidak adanya pengelompokan siswa antara kelas unggulan ataupun kelas non unggulan, dan belum pernah adanya penelitian yang dilaksanakan menggunakan model pembelajaran Scramble berbantuan permainan crossword fuzle di SD gugus tersebut. Penelitian ini dilaksanakan pada semester genap tahun ajaran 2017/2018 dalam jangka waktu \pm 5 bulan.

Jenis penelitian yang dilakukan dalam penelitian ini adalah penelitian kuantitatif dengan desain eksperimen yang digunakan yaitu "Nonequivalent control group design". "Dalam rancangan ini, subjek penelitian atau partisipan penelitian tidak dipilih secara acak untuk dilibatkan dalam kelompok eksperimen dan kelompok kontrol. Dalam rancangan ini pula, ada dua kelompok subjek satu mendapatkan perlakuan dan satu kelompok sebagai kelompok kontrol. Keduanya memperoleh prates dan pascates."(Setyosari, 2015:210).

Pelaksanaan penelitian terdiri dari tiga tahapan yaitu, tahap persiapan, tahap pelaksanaan, dan tahap akhir eksperimen.

Populasi dalam penelitian ini adalah seluruh siswa kelas IV (empat) SD Gugus I Gusti Ngurah Rai Denpasar Utara tahun ajaran 2017/2018, yang terdiri 323 orang yang tersebar dalam dari 9 kelas.

Berdasarkan hasil wawancara yang diperoleh dari kepala sekolah serta guru kelas IV di masingmasing SD Gugus I Gusti Ngurah Rai Denpasar Utara yaitu bahwa kelas IV terdiri dari 4 sekolah dengan 9 kelas yang ada di Gugus I Gusti Ngurah Rai Denpasar Utara setara secara akademik yang memiliki nilai rata-rata tidak jauh berbeda. Dikatakan setara, karena pengelompokan siswa kedalam kelas-kelas dari 4 sekolah yang ada disebar secara merata antara siswa yang memiliki kemampuan tinggi, sedang, dan rendah. Dari keterangan tersebut berarti tidak terdapat kelas unggulan maupun non unggulan.

Teknik pengambilan sampel pada penelitian ini adalah Random Sampling yang dirandom kelasnya, sehingga setiap kelas mendapatkan peluang yang sama untuk menjadi sampel penelitian. Pemilihan sampel penelitian ini tidak dilakukannya pengacakan individu melainkan hanya pengacakan kelas. Karena tidak bisa mengubah kelas yang telah terbentuk sebelumnya. Kelas dipilih sebagaimana telah terbentuk tanpa campur tangan peneliti dan tidak dilakukannya pengacakan individu, kemungkinan pengaruhpengaruh dari keadaan siswa mengetahui dirinya dilibatkan dalam eksperimen dapat dikurangi sehingga penelitian ini benar-benar menggambarkan pengaruh perlakuan yang diberikan.

Dari empat Sekolah Dasar yang ada di Gugus I Gusti Ngurah Rai, dilakukan pengundian. Pengundian dilakukan untuk memilih dua kelas yang dijadikan sampel penelitian. Pengundian dilakukan sebanyak dua kali untuk menentukan antara kelas eksperimen dan kelas kontrol. Kelas yang muncul pertama langsung dipilih menjadi kelas eksperimen dan kelas yang muncul pada undian kedua dijadikan sebagai kelas kontrol.

Berdasarkan undian yang dilakukan, kelas IV A SD N 4 Ubung yang berjumlah 34 siswa muncul pertama dan dijadikan sebagai kelas eksperimen, sedangkan Kelas IV SD N 3 Ubung yang berjumlah 36 siswa muncul pada undian kedua dan dijadikan sebagai kelas kontrol. Pada kelas eksperimen diberikan perlakuan berupa model pembelajaran scramble bebantuan permainan crossword fuzle dan pada kelas kontrol dibelajarkan dengan pembelajaran konvensional.

Untuk mengetahui kesetaraan pada kelas sampel yang ada di SD Gugus I Gusti Ngurah Rai maka diberikan pre test dan hasil dari pre test tersebut diuji kesetaraannya dengan rumus uji-t yakni dengan polled variant.

Adapun validitas internal dan eksternal dari penelitian ini adalah validitas internal dalam penelitian ini dapat berupa bias seleksi, pengujian sebelumnya (pretesting), instrumentasi, kematangan atau maturasi (maturation), sikap subjek dan faktor harapan, sedangkan validitas eksternal yaitu interaksi antara perlakuan dan orang; dan interaksi antara perlakuan dan latar.

Metode pengumpulan data yang digunakan pada penelitian ini adalah metode tes.Tes yang digunakan untuk mengukur penguasaan kompetensi pengetahuan IPA berupa tes objektif dalam bentuk pilihan ganda biasa yang dilengkapi dengan 4 pilihan jawaban (a, b, c, dan d). ). Jumlah butir soal disusun berdasarkan kisi-kisi tes kompetensi pengetahuan IPA sebanyak 50 butir soal yang kemudian diuji cobakan pada kelas yang jenjangnya lebih tinggi. Jumlah siswa yang terlibat uji coba instrumen dalam penelitian ini yakni 32 orang dari siswa kelas V di SDN 4 Ubung. Dari 50 butir soal yang telah diujikan maka diperoleh 37 butir soal yang dinyatakan layak untuk digunakan dalam peneitian ini. 
Dalam penelitian ini dikemukakan definisi operasional dari masing-masing variabel. Dimulai dari variabel terikat yaitu kompetensi pengetahuan IPA. Kompetensi pengetahuan IPA adalah perubahan perilaku siswa yang mencerminkan kemampuan siswa terhadap penguasaan materi pembelajaran IPA dari kemampuan berpikir meliputi mengingat, memahami/mengerti, menerapkan, menganalisis, mengevaluasidan dimensi pengetahuan, faktual dan konseptual yang diukur menggunakan skor dari tes kompetensi pengetahuan setelah mengalami proses belajar. Variabel bebas dari penelitian ini yaitu model pembelajaran scramble berbantuan permainan crossword fuzle. Melalui model pembelajaran scramble ini melatih siswa untuk berpikir cepat dan tepat, melatih kedisiplinan siswa dan mendorong pemahaman siswa terhadap materi pelajaran dengan bantuan teman-temannya sesama siswa. Kemudian untuk meninjau ulang tingkat pemahaman siswa terkait dengan materi yang telah dijelaskan maka dibantu dengan permainan crossword fuzle. Selain menstimulasi siswa agar lebih aktif, adanya permainan ini juga membuat suasana menjadi lebih menyenangkan bagi siswa sehingga siswa tidak akan merasakan bosan saat proses pembelajaran dan hasil belajar menjadi lebih optimal.

Setelah data dalam penelitian ini terkumpul, maka selanjutnya dilakukan analisis data. Dalam menganalisis data ini digunakan metode analisis statistik deskriptif dan statistik inferensial. Adapun penyajian data yang digunakan pada metode analisis statistik deskriptif, yaitu perhitungan rata-rata (mean), standar deviasi dan varian hasil kompetensi pengetahuan IPA.

Analisis data statistik inferensial digunakan untuk menganalisis data dengan menguji hipotesis penelitian dan menarik kesimpulan terhadap hipotesis. Untuk menguji hipotesis penelitian menggunakan uji perbedaan rata-rata data gain skor. Sebelum dilakukan uji hipotesis terlebih dahulu dilakukan uji prasyarat analisis data. Pada uji prasyarat analisis data dilakukan uji normalitas sebaran data dan uji homogenitas varians.

Uji Normalitas dimaksudkan untuk mengetahui sebaran data skor penguasaan kompetensi pengetahuan IPA siswa masing-masing kelompok berdistribusi normal atau tidak. Uji Normalitas sebaran data dalam penelitian ini menggunakan uji Kolmogorov-smirnov. Kriteria pengujian adalah pada taraf signifikansinya adalah $5 \%$ dan derajat kebebasannya n-1, jika KShitung $<$ KStabel, maka ho diterima (gagal ditolak) yang berarti data berdistribusi normal.

Uji homogenitas varians dilakukan dengan uji F. Kriteria pengujian, pada taraf signifikan $5 \%$ dengan derajat kebebasan untuk pembilang n1-1 dan derajat kebebasan untuk penyebut n2-1.jika Fhit $<$ F_tabel maka sampel homogen.

Data yang diperoleh sudah memenuhi prasyarat uji normalitas dan homogenitas maka analisis yang digunakan adalah statistik parametrik. Analisis statistik yang digunakan untuk menguji hipotesis penelitian ini adalah uji beda mean (uji t). Uji Hipotesis menggunakan uji-t dengan rumus polled varians. Rumus uji-t dengan rumus polled varians digunakan bila jumlah anggota sampel $n 1 \neq n 2$ dan varians homogen. Dengan criteria, pada taraf signifikan $5 \%$ dengan $\mathrm{dk}=\mathrm{n} 1+\mathrm{n} 2-2$, jika harga thitung $<$ ttabel, maka Ho diterima, dan jika harga thitung >ttabel maka Ho ditolak.

\section{ANALISIS DAN PEMBAHASAN}

Data penguasaan kompetensi pengetahuan IPA siswa kelas IVA SD N 4 Ubung sebagai kelompok eksperimen yang dibelajarkan menggunakan model pembelajaran scramble berbantuan permainan crossword fuzle menunjukkan bahwa nilai gain skor tertinggi yang dicapai siswa adalah 0,78 sedangkan nilai gain skor terendah yang dicapai siswa adalah 0,22 . Data penguasaan kompetensi pengetahuan IPA siswa kontrol yang dibelajarkan menggunakan model pembelajaran konvensional menunjukkan bahwa nilai gain skor tertinggi yang dicapai siswa adalah 0,67 sedangkan nilai gain skor terendah yang dicapai siswa adalah 0,08 .

Berdasarkan hasil gain skor yang diperoleh dengan membandingkan antara selisih nilai post test dan pre test dengan selisih nilai maksimal dan nilai pre test. Hasil rata-rata gain skor kelompok eksperimen yaitu 0,505. Rata-rata gain skor kompetensi pengetahuan IPA tersebut kemudian dikonversikan pada tabel kriteria peningkatan gain skor, sehingga dapat diketahui kompetensi pengetahuan IPA siswa kelompok eksperimen pada kategori sedang. Sedangkan hasil rata-rata gain skor kelompok kontrol yaitu 0,331. Kemudian rata-rata gain skor kompetensi pengetahuan IPA tersebut dikonversikan pada tabel kriterian peningkatan gain skor, sehingga dapat diketahui kompetensi pengetahuan IPA siswa kelompok kontrol pada kategori sedang. Sesuai dengan hasil analisis data kompetensi pengetahuan IPA menunjukkan bahwa rata-rata gain skor kompetensi pengetahuan IPA siswa

kelompok eksperimen $\bar{x}=0,505>\bar{x}=0,331$ rata-rata gain skor kompetensi pengetahuan IPA siswa kelompok kontrol. 
Sebelum dilakukan pengujian hipotesis dengan analisis uji-t, terlebih dahulu harus dilakukan uji prasyarat yang meliputi uji normalitas data dan uji homogenitas varians. Berdasarkan hasil analisis diperoleh harga $\mathrm{KS}_{\text {hitung }}=0,110$ untuk kelas eksperimen. Harga tersebut kemudian dikonsultasikan dengan harga $\mathrm{KS}_{\text {tabel }}$ dengan $\mathrm{dk}=5$ dan taraf signifikan $5 \%$ sehingga diperoleh harga $\mathrm{KS}_{\text {tabel }}=0,242$. Karena $\mathrm{KS}_{\text {hitung }}=0,110<\mathrm{KS}_{\text {tabel }}=0,242$ maka $\mathrm{H}_{0}$ diterima (gagal ditolak). Ini berarti sebaran data penguasaan kompetensi pengetahuan IPA kelas eksperimen berdistribusi normal. Sedangkan pada kelas kontrol, harga $\mathrm{KS}_{\text {hitung }}=0,095$ Harga tersebut kemudian dikonsultasikan dengan harga $\mathrm{KS}_{\text {tabel }}$ dengan $\mathrm{dk}=$ 5 dan taraf signifikan 5\% sehingga diperoleh harga $\mathrm{KS}_{\text {tabel }}=0,224$. Karena $\mathrm{KS}_{\text {hitung }}=0,095<\mathrm{KS}_{\text {tabel }}=0,224$ maka $\mathrm{H}_{0}$ diterima (gagal ditolak). Ini berarti sebaran data penguasaan kompetensi pengetahuan IPA kelas kontrol berdistribusi normal.

Setelah data yang di uji berdistribusi normal, selanjutnya dilakukan uji homogenitas varian. Adapun hasil uji homogenitas data penguasaan kompetensi pengetahuan IPA siswa kelas eksperimen dan kelas kontrol diperoleh $F_{\text {hitung }}=1,09$. Nilai tersebut kemudian di konsultasikan dengan harga $F_{\text {tabel }}=1,80$ dengan dk (33,35). Karena $F_{\text {hitung }}=1,09<F_{\text {tabel }}=1,80$ maka dapat dikatakan data penguasaan kompetensi pengetahuan IPA kelas eksperimen dan kelas kontrol mempunyai varians yang homogen.

Berdasarkan hasil uji normalitas dan homogenitas dapat diketahui bahwa data yang diperoleh dari kelas eksperimen dan kelas kontrol berdistribusi normal dan memiliki varians yang homogen. Karena data yang diperoleh telah memenuhi uji prasyarat, maka uji hipotesis dapat dilakukan dengan menggunakan analisis uji-t dengan rumus polled varians. Pada taraf signifikan $5 \%$ dengan dk $=n_{1}+n_{2}-2$, $\mathrm{dk}=(34+36)-2=68$. Berikut disajikan rekapitulasi hasil analisis data dengan menggunakan uji $\mathrm{t}$ pada Tabel 1.

Tabel 1. Rekapitulasi Hasil Analisis Data Kompetensi Pengetahuan IPA Menggunakan Uji-t

\begin{tabular}{lllllllll}
\hline No. & Sampel & $\mathbf{N}$ & Dk & Mean & $\mathbf{S}^{2}$ & $\boldsymbol{t}_{\text {hitung }}$ & $\boldsymbol{t}_{\text {tabel }}$ & Status \\
\hline 1. & $\begin{array}{l}\text { Kelas } \\
\text { eksperimen }\end{array}$ & 34 & & 0,505 & 0,024 & & & \\
& Kelas Kontrol & 36 & 68 & & & 4,833 & 2,000 & $\mathrm{H}_{0}$ ditolak \\
\hline
\end{tabular}

Dari hasil analisis uji $\mathrm{t}$ diperoleh $\mathrm{t}_{\text {hitung }}=4,833$. Harga tersebut kemudian dibandingkan dengan harga $t_{\text {tabel }}$ dengan $\mathrm{dk}=(34+36)-2=68$ dan taraf signifikansi $5 \%$ sehingga diperoleh harga $t_{\text {tabel }}=2,000$. Karena $t_{\text {hitung }}>t_{\text {tabel, }} t_{\text {hitung }}=4,833>t_{\text {tabel }}=2,000$ maka $H_{0}$ ditolak. Sehingga dapat dikatakan bahwa terdapat perbedaan yang signifikan penguasaan kompetensi pengetahuan IPA atara kelompok siswa yang dibelajarkan menggunakan model pembelajaran scramble berbantuan permainan crossword fuzle dan kelompok siswa yang dibelajarkan menggunakan pembelajaran konvensional pada siswa kelas IV SD Gugus I Gusti Ngurah Rai Denpasar Utara tahun ajaran 2017/2018.

Pembelajaran tematik pada muatan materi IPA pada kelompok yang dibelajarkan menggunakan model pembelajaran scramble berbantuan permainan crossword fuzle berjalan dengan baik dan kondusif. Karena dalam proses pembelajaran, siswa tidak hanya berpikir, menulis, bertanya, atau berbicara saja, akan tetapi mereka juga menerka dengan cepat dan tepat jawaban soal yang sudah tersedia namun masih dalam kondisi acak. Melalui model pembelajaran scramble ini siswa dilatih untuk tidak sekedar memahami dan menemukan susunan teks yang baik dan logis, tetapi juga dilatih untuk berpikir kritis analitis dengan bantuan teman-temannya. "Satu hal yang penting dalam model ini, siswa tidak sekedar berlatih memahami dan menemukan susunan teks yang baik dan logis, tetapi juga dilatih untuk berpikir kritis analitis" (Shoimin, 2014:168). Selain itu proses pembelajaran lebih menyenangkan karena dibantu dengan permainan crossword fuzle yang pada dasarnya sudah tidak asing lagi bagi para siswa dan mudah dalam memainkannya. Hal tersebut dapat menstimulasi semangat siswa dalam mengerjakan soal yang diberikan dan dalam mengikuti pembelajaran.

Dengan demikian, pembelajaran menggunakan model pembelajaran scramble berbantuan permainan crossword fuzle pada penelitian ini memiliki keunggulan, yaitu melatih siswa untuk berpikir cepat dan tepat, melatih kedisiplinan siswa, semua siswa dapat terlibat aktif dan mendorong pemahaman siswa terhadap materi pelajaran dengan bantuan teman-temannya sesama siswa serta menyenangkan karena dipadukan dengan permainan yang mampu menstimulasi siswa sehingga lebih bersemangat dalam mengikuti proses pembelajaran.

Hasil penelitian ini memperkuat penelitian yang dilakukan oleh Suryanta (2014). Berdasarkan hasil analisis data dari hasil penelitian yang telah dilakukan, diperoleh thitung $=3,18>$ ttabel $=2,00$ pada taraf signifikansi 5\%. Dari rata-rata hitung, ditemukan rata-rata hasil belajar IPA siswa pada kelompok eksperimen adalah 77,05 dan rata-rata kelompok kontrol adalah 69,21, sehingga dapat disimpulkan 
bahwa penerapan model pembelajaran scramble berbantuan media gambar animasi berpengaruh terhadap hasil belajar IPA siswa kelas V SD Gugus Yos Sudarso Denpasar Selatan Tahun Pelajaran 2013/2014. Penelitian yang kedua dilakukan oleh Ramadani (2014). Berdasarkan hasil analisis data dari hasil penelitian yang telah dilakukan, diperoleh thitung $=9,125>$ ttabel $=1,671$ pada taraf signifikansi $5 \%$. Dari rata-rata hitung, ditemukan rata-rata hasil belajar IPA siswa pada kelompok eksperimen adalah 21,03 dan rata-rata kelompok kontrol adalah 13,73, sehingga dapat disimpulkan bahwa pembelajaran dengan menggunakan model pembelajaran scramble berbantuan kartu pertanyaan berpengaruh signifikan terhadap hasil belajar IPA pada siswa kelas V SD di Desa Dauhwaru Kecamatan Jembrana Kabupatan Jembrana Tahun Pelajaran 2013/2014. Astuti (2017) dalam penelitiannya menyatakan bahwa model pembelajaran Scramble berbantuan kartu pertanyaan berpengaruh signifikan terhadap hasil belajar Bahasa Indonesia siswa kelas III di Gugus I Kecamatan Buleleng Kabupaten Buleleng Tahun Pelajaran 2016/2017. Penelitian oleh Widiantari (2013) menunjukkan bahwa hasil belajar IPA yang dicapai oleh kelas yang mengikuti pembelajaran dengan model pembelajaran scramble berbantuan media videolebih tinggi dibandingkan dengan kelas yang mengikuti pembelajaran dengan model pembelajaran Konvensional.

\section{KESIMPULAN}

Berdasarkan penelitian yang telah dilakukan maka dapat ditarik simpulan yaitu kompetensi pengetahuan IPA kelompok eksperimen yang dibelajarkan menggunakan model pembelajaran scramble berbantuan permainan crossword fuzle pada siswa kelas IV SD Gugus I Gusti Ngurah Rai tahun ajaran $2017 / 2018$ diperoleh skor rata -rata gain skor $X=0,505$ dengan nilai gain skor tertinggi 0,78 dan nilai gain skor terendah 0,22. Rata-rata gain skor kompetensi pengetahuan IPA tersebut kemudian dikonversikan pada tabel kriteria peningkatan gain skor, sehingga dapat diketahui kompetensi pengetahuan IPA siswa kelompok eksperimen berada pada kategori sedang. Kompetensi pengetahuan IPA kelompok yang dibelajarkan menggunakan pembelajaran konvensional pada siswa kelas IV SD Gugus I Gusti Ngurah Rai tahun ajaran 2017/2018 diperoleh skor rata -rata gain skor $X=0,331$ dengan nilai gain skor tertinggi 0,67 dan nilai gain skor terenda 0,08. Rata-rata gain skor kompetensi pengetahuan IPA tersebut kemudian dikonversikan pada tabel kriteria peningkatan gain skor, sehingga dapat diketahui kompetensi pengetahuan IPA siswa kelompok kontrol berada pada kategori sedang. Berdasarkan hasil analisis dengan menggunakan uji-t diperoleh harga thitung $=4,833$ dan harga ttabel dengan $\mathrm{dk}=68$ pada taraf signifikansi $5 \%$ diperoleh ttabel $=2,000$. Maka thitung $=4,833>$ ttabel $=2,000$ ini berarti bahwa terdapat perbedaan yang signifikan kompetensi pengetahuan IPA kelompok yang dibelajarkan menggunakan model pembelajaran scramble berbantuan permainan crossword fuzle dan kelompok siswa yang dibelajarkan menggunakan pembelajaran konvensional pada siswa kelas IV SD Gugus I Gusti Ngurah Rai Tahun Ajaran 2017/2018 pada tema 8 (Daerah Tempat Tinggalku). Rerata kompetensi pengetahuan IPA yang diperoleh kelompok yang dibelajarkan menggunakan model pembelajaran scramble berbantuan permainan crossword fuzle lebih tinggi dari kelompok yang dibelajarkan menggunakan pembelajaran konvensional $(0,505>0,331)$. Dengan demikian dapat disimpulkan bahwa terdapat pengaruh model pembelajaran scramble berbantuan permainan crossword fuzle terhadap kompetensi pengetahuan IPA pada siswa kelas IV SD Gugus I Gusti Ngurah Rai Tahun Ajaran 2017/2018.

Berdasarkan hasil penelitian, pembahasan dan simpulan, maka dapat diajukan beberapa saran kepada beberapa pihak sebagai berikut. (1) Kepada Guru, penelitian ini agar bisa dijadikan acuan untuk meningkatkan keterampilan dalam merancang pembelajaran dengan tujuan memperoleh hasil belajar yang optimal. Guru yang mengajar menggunakan tematik disarankan agar mengembangkan inovasi pembelajaran dengan menerapkan model pembelajaran scramble berbantuan permainan crossword fuzle agar mampu mengoptimalkan pembelajaran siswa. (2) Kepada Sekolah, Sekolah melalui Kepala Sekolah agar memberikan sosialisasi secara berkelanjutan mengenai inovasi-inovasi pembelajaran kepada guru dalam membelajarkan siswa agar dapat mengoptimalkan hasil belajar siswa sehingga mutu sekolah menjadi semakin meningkat. (3) Kepada Peneliti, bahwa dalam penelitian ini terbatas pada pokok bahasan tematik tema 8 (Daerah Tempat Tinggalku) siswa kelas IV. Untuk memperoleh kompetensi yang berbeda dan pada muatan materi yang berbeda disarankan kepada peneliti lainnya untuk melakukan penelitian pada pokok bahasan yang lebih beragam untuk memperoleh hasil yang lebih baik.

\section{DAFTAR PUSTAKA}

Artini, A. A. Ayu Sri Vidya, I Wyn. Sujana, I Km. Ngurah Wiyasa. 2014. Pengaruh Model Pembelajaran Scramble Berbantuan Media Semi Konkret Terhadap Hasil Belajar Ips Siswa Kelas V Sd Gugus 
Kapten Kompiang Sujana. e-Journal PGSD Universitas Pendidikan Ganesha Jurusan PGSD Vol. 2 No. 1.

Astuti, Ni Made Dwi Kurni, Made Sumantri, I Komang Sudarma. 2017. Pengaruh Model Pembelajaran Scramble Terhadap Hasil Belajar Bahasa Indonesia Siswa Kelas Iii Kecamatan Buleleng . e-Journal PGSD Universitas Pendidikan Ganesha Mimbar PGSD Vol. 5 No. 2.

Diena, Bianca Bella, Pujiastuti, Siti Murdiyah. 2015. Penerapan Metode Pembelajaran Scramble dan Time Token untuk Meningkatkan Motivasi dan Hasil Belajar Siswa Kelas XI IPA 2 SMA Negeri 3 Jember (Pokok Bahasan Sistem Reproduksi Manusia). JURNAL EDUKASI, Volume II (3): pp. 17-21

Handayani, Sri, Rena Lestari, Dahlia. 2015. Pengaruh Model Pembelajaran Scramble Terhadap Hasil Belajar Siswa Kelas Vii Di Smp Negeri 2 Satu Atap Kepenuhan Hulu Tahun Pembelajaran 2014/2015. E-journal Mahasiswa Prodi Biologi Volume 1 Nomor 1

Mulyasa, E. 2009. Kurikulum Tingkat Satuan Pendidikan. Bandung: PT Remaja Rosdakarya.

Kosasih, E. 2014. Strategi Belajar dan Pembelajaran Implementasi Kurikulum 2013. Bandung: Trama Widya.

Huda, Miftahul. 2013. Model-Model Pengajaran dan Pembelajaran. Yogyakarta: Pustaka Pelajar.

Ngalimun, dkk. 2016. Strategi dan Model Pembelajaran. Yogyakarta: Aswaja Pressindo.

Rachmawati, S., Muchtar, I., \& Shaleh U. H. M. (2014). Peningkatan Aktivitas dan Hasil Belajar Siswa Kelas VI Mata Pelajaran PKn Materi Pokok Demokrasi Melalui Penerapan Model Pembelajaran Scramble di SD Negeri Kademangan 1 Bondowoso (Versi elektronik). Jurnal Edukasi UNEJ, I (I), 10-14. Diperoleh pada tanggal 20 November 2016 dari: http://jurnal.unej.ac.id/inde x.php/JEUJ/article/view/10 26/823

Ramadani. 2014. "Pengaruh Model Pembelajaran Scramble Berbantuan Kartu Pertanyaan Terhadap Hasil Belajar IPA Siswa Kelas V SD”. EJournal Mimbar PGSD Universitas Pendidikan Ganesha Jurusan PGSD (Vol: 2 No: 1 Tahun 2014). Diakses tanggal 31 Desember 2016.

Setyosari, Punaji. 2015. Metode Penelitian Pendidikan dan Pengembangan. Jakarta: Prenadamedia Group.

Sholihah, Annis Fathimatus, Suripto, Tri Saptuti Susiani. 2017. Penerapan Model Scramble Dengan Media Flashcard Dalam Peningkatan Pembelajaran Ips Tentang Koperasi Pada Siswa Kelas Iv Sd Negeri Karangkemiri 01 Tahun Ajaran 2016/2017. KALAM CENDEKIA, Volume 5, Nomor 5.1, hlm. $380-384$

Shoimin, Aris. 2014. 68 Model Pembelajaran Inovatif dalam Kurikulum 2013. Yogyakarta: Ar-Ruzz Media.

Sodiqin, Ahmad, Sugiyono ., Nursyamsiar Tirtowarti. 2015. Pengaruh Pembelajaran Kooperatif Metode Scramble Terhadap Hasil Belajar Ips Di Sekolah Dasar. Jurnal Pendidikan dan Pembelajaran Vol. 4 No 9.

Sudarmi, dan Burhanuddin. 2017. Keefektifan Model Pembelajaran Kooperatif Tipe Scramble Dalam Keterampilan Menulis Kalimat Bahasa Jerman Siswa Kelas Xi Sma Negeri 11 Makassar . Eralingua : Jurnal Pendidikan Bahasa Asing dan Sastra Volume 1 No.1

Suryanta, I Made. 2014. "Pengaruh Model Pembelajaran Scramble Berbantuan Media Gambar Animasi Terhadap Hasil Belajar IPA Siswa Kelas V SD Gugus Yos Sudarso Denpasar". Mimbar PGSD Universitas Pendidikan Ganesha, Volume 2, Nomor 1 (hlm 1-10). Tersedia pada http://ejournal.undiksha.ac.id/index.php/JJPGSD/article/view/1972 (diakses pada tanggal 3 Mei 2018).

Undang-Undang Republik Indonesia Nomor 20 Tahun 2003 tentang Sistem Pendidikan Nasional. 2003. Jakarta: Presiden Republik Indonesia.

Widiantari, Ni Nym. H. Syahruddin, I W. Widiana. 2013. Pengaruh Model Pembelajaran Scramble Berbantuan Media Video Terhadap Hasil Belajar Ipa Siswa Kelas Iv Sd Di Gugus V Kecamatan Buleleng. Jurnal Mimbar PGSD Universitas Pendidikan Ganesha Volume 1 Nomor 1. 